\title{
Selective Use of Concurrent Chemotherapy in Elderly Cervical Cancer Patients Treated with Definitive Radiotherapy: Experience from Two Institutions [Erratum]
}

\author{
You K, Peng H, Jiang Y, Bi Z, Qiu X. Cancer Manag Res. \\ 2019;11:4815-4823.
}

The email address of Zhuo-Fei Bi is missing from the correspondence section on page 4815 . This error was introduced by the Editorial staff during the publication process. The correspondence section should read as follows:
Correspondence: Xing-Sheng Qiu; Zhuo-Fei Bi

Department of Radiation Oncology, SunYat-Sen Memorial Hospital, SunYat-Sen University, 107\# Yan jiang Road, Guangzhou 510120, People's Republic of China

Tel +862081332536

Fax +862081332536

Email qiuxingsheng@sina.cn; bizhuof@mail3.sysu.edu.cn

\section{Publish your work in this journal}

Cancer Management and Research is an international, peer-reviewed open access journal focusing on cancer research and the optimal use of preventative and integrated treatment interventions to achieve improved outcomes, enhanced survival and quality of life for the cancer patient.
The manuscript management system is completely online and includes a very quick and fair peer-review system, which is all easy to use. Visit http://www.dovepress.com/testimonials.php to read real quotes from published authors. 